\title{
SPECIFICITIES OF THE MUTUAL INFLUENCE OF CONTEXT AND ASSESSMENT IN FRENCH EVALUATIVE UTTERANCES
}

\author{
Halyna Moroshkina \\ Zaporizhzhia National University \\ g.moroshkina@gmail.com
}

\begin{abstract}
The paper is focused on the study of the interconnection of context and evaluative utterances in French. The assessment of different aspects of the world is viewed as a considerable part of human cognitive activities. Considering this, in the paper evaluative utterances are analysed in relation to logical, semantic, pragmatic and communicative properties of evaluation as an element of a linguo-cognitive domain. It is emphasised that the pragmatic analysis is of great significance in the interpretation and explanation of positive or negative polarity of the utterance evaluation. The present article also demonstrates the importance of various semasiological and syntactic expressive means and stylistic devices in the process of highlighting the positive or negative evaluative effect. Following the principles of pragmatic analysis, the author outlines the language means realising positive and negative polarity of the utterance evaluation. The study also proves that the units being neutral at the language level acquire evaluative potential in context. The results obtained confirm the idea that the correlation between the evaluative utterance and its context helps understand the encoded in the evaluative utterance presupposition of communication being the speaker's communicative intentions associated with his/her epistemic state.
\end{abstract}

Keywords: assessment; evaluative utterance; context; pragmatic; expressive means; stylistic devices.

\section{Introduction}

The majority of linguists are unanimous in the fact that there is a close connection between the evaluative utterance and the context. In this regard, Ch. Bally wrote that "in each individual situation and in each context, the speech sign cannot reveal all its possible shades of meaning; in each case, only one of them is at the forefront, and it temporarily pushes the other meanings to the background. The dominant feature of a speech sign can be revealed in the context only" (Bally, 2001, p. 181).

At present the notion of context has several interpretations and classifications of its varieties. Scientists (Fedoriv, 2016, pp. 1-36; Kecskes, 2013; Saveliuk, 2015, pp. 61-62) distinguish three main types of context: 1) verbal context (i.e. linguistic material preceding and following the focal word); 2) situational context (i.e. a set of cultural and psychological data common to the interlocutors); 3) cognitive context (i.e. a mental base, formed at the moment of assimilation of the meanings of a particular text).

Bloomfield (2010) considers that the notion of "context" includes its two subtypes: verbal and situational (p. 243). Catford (1974) introduces an additional term for the verbal context - a co-text which is determined by the situational context (p. 31). Koseriu (2010) distinguishes linguistic, discourse, and external context in relation to the discourse types. He also emphasises the distinction between positive and negative contexts.

Vinogradov (2001) directly relates the analysis of the word meaning to the study of its contextual environment. According to him, the meaning of a word is determined not only by its correspondence to the concept expressed with the help of this word, but it also depends on the contexts of its use, and on its specific lexical relationships with other words, as defined by the laws of combination of meanings inherent to a given language (p. 20). At the same time, the scientist adheres to the point of view that regardless of the definite case of its usage, the word is present in the speaker's consciousness with all its possible meanings, hidden and potential, ready to emerge at any time (p. 21).

It should also be noted that pragmatic studies in the late 20th century led to the conclusion that any utterance can be interpreted only in context. The linguistic analysis contributes to the adequate interpretation of an utterance, but without a contextual analysis, characterised by a complex nature (which includes, apart from the linguistic matter, the situation, participants, space-time relationship, and sociocultural features) it cannot be demonstrative. Pragmatic interpretations, according to Grice (1975), are performed by inferential processes based on the method of deduction.

Present-day linguist studies (Akman, 2000, pp. 743-759; Fetzer, 2004; Kachru, 2008; Kolegaeva, 2017, pp. 36-43) emphasise the dynamic connection between the meaning of a word and its context. Context provides an opportunity to reveal the hidden potential of a word. Words encode previous experience and former contexts of the use of a certain expression or utterance. In the communication act, the former contextual use of a word clashes with the actual one. The actual communicative meaning of a word is generated as a result of a collision of the "old", previous contexts encoded in lexical units and the actual 
situational context in which this utterance is used. The personal contexts of the speaker and hearer, encoded in the same words, are based on personal experiences and often differ even in the same linguistic expressions.

Our understanding of a context is based on its pragmatic interpretation, since "the notion of pragmatic context is a theoretical and cognitive abstraction of a variety of physical, biological, and other possible situations" (Dijk, 1977, p. 19). The pragmatic context provides information not only on the conditions under which the expression is perceived, but also gives rise to expectations regarding the probable goals of the participants, and therefore, regarding possible speech acts that can be carried out in this situation. In other words, the pragmatic context, which serves to express the meaning of an utterance in speech, is formed by a set of subordinate contexts: linguistic, stylistic, paralinguistic, situational, cultural, and psychological. It is within the framework of the pragmatic context that the transition in the use and perception of the utterance from the level of meaning to the level of sense, in particular, its pragmatic interpretation, takes place. The addressee's awareness of this sense is qualified as the understanding of an utterance. Context is no longer considered as an objective phenomenon but as specific mental creation generated by interlocutors in the process of communication (Stanley, 2007). This approach to context understanding is undoubtedly crucial, though, in terms of the study of the evaluative utterance potential, the knowledge of all conditions under which it occurs is necessary.

Bearing all this in mind, the aim of this paper is to examine specific contextual means expressing the potential of evaluation as well as to define the interrelation of the context and evaluative utterances.

\section{Data and methodology}

The material, which is subjected to the analysis, is a selection of approximately 550 evaluative utterances from the work by a contemporary French writer F. Sagan. The criterion of the selection was the presence (direct or indirect) of an evaluative seme in words within the utterance.

The methodology applied in the study is based on the essential points of Evaluation theory and the theory of Context, which present basic ideas for the linguistic study (Arutyunova, 2012; Dijk, 2009; Kecskes, 2013; Prihodko, 2016; Prihodko, 2018; Vol'f, 2009). This research involves a variety of methods. A descriptive method, by which we mean a set of research techniques that allow one to move from particular observations to generalisations and conclusions is widely used; methods of contextual and presuppositional analyses, allowing one to detect the influence of the role structure of the communication situation, social factors on the communicative semantics and functional features of utterances with evaluative words and phrases.

\section{Results and Discussion}

\section{Evaluation as the Source of Evaluative Utterances}

Human activity is traditionally viewed as a pragmatic concern. However, the application of this approach can be appropriate only when it is aimed at those phenomena and things which can be treated as something useful, practical and valuable. In turn, evaluation is an essential component of cognition, which is based on a value approach to the phenomena of nature and society. All objects of reality perceived by a human being have a certain value in his/her mind, that is, they may be evaluated.

Evaluation is defined as the speaker's objective or subjective attitude to a certain object, which is explicitly or implicitly expressed by linguistic means (Prihodko, 2016, p. 17). According to Arutyunova's remark (2012, p. 181), the nature of evaluation always corresponds to the nature of an individual since we assess only "what is needed (physically and spiritually) to man and to Mankind". It follows that a person's life and activities are impossible without evaluation.

It should be stressed that a specific feature of evaluation is its selectivity. The person's mind always extracts and stores those features of the surrounding world that are significant to the individual from the evaluative point of view. There is no doubt that one and the same thing can be of great importance to one person and of no interest to another. If a certain object has not affected the person's psychic sphere, no evaluation will be formed either in thought or in speech.

People assess a wide range of different phenomena: their past and present, the appearance and behaviour of the individual, the form and size of various subjects, things, duration and regularity of events, the degree of complexity of tasks, etc. Scholars believe that evaluative interpretations of the state of affairs belong to one of the most important types of mental-speech activities in the everyday life of any person (Byessonova, 2012, pp. 7-14). This has resulted from the observation that objective reality is examined and analysed by an individual from the point of view of its evaluative character - good and evil, truth and falsehood, justice and injustice, benefit and harm, beauty and ugliness (Partington, 2017, p. 192). The speaker and the listener form 
a different reflection of a communicative situation in their mental space, and it is clearly realised in the evaluative context (Myroniuk, 2017, p. 103; Samokhina, Pasynok, 2017, pp. 287-288).

Thus, it is commonly agreed that all the shades of evaluation can be vividly seen only when an utterance is plunged into the context (micro- or macrocontext) and determined by a number of linguistic and extralinguistic factors. This justifies the fact that the study of the utterance evaluative potential requires carrying out the analysis of such an important aspect as the influence of context on the formation of evaluative utterances.

\section{Interconnection of context and evaluative utterances in the French Language}

Continuing the study of the mutual influence of context and evaluation in a piece of literature, we turn to one of the Western European languages, namely French. Using this material, we want to identify the possible specific features of interconnection between the evaluative utterance and the context of its actualisation. As a test corpus, the novel "Magic Clouds" ("Les merveilleux nuages") by Francoise Sagan served as the language object of the analysis.

The following example shows that the most important things happen in the characters' psychic sphere. It is a constant attempt to unravel a complex tangle of emotions in an intellectual way. As one can see from the example, sometimes it is better for a person to live in the illusory world rather than face the truth:

(1) "Pour la première fois depuis un an elle pensait qu'il y avait d'autres hommes qu'Alan sur la terre. "Il est trop maladroit", pensa-t-elle tout haut. Il gâche tout." (Sagan, 1961, p. 20).

This example shows that the context, once considered neutral, can change the polarity of the evaluation of its utterances. The main character of the novel, Josée, a year after her marriage, realises and declares out loud that Alan is not the only man in the whole world. She emphasises that he is awkward and spoils everything around him. The negative evaluation is formed in this case by a number of the utterance components. It is common knowledge that thinking is characterised as an individual mental process occurring in the person's mind. The exteriorisation of Josée's thoughts (pensa tout haut) indicates an explosion of emotions of indignation, a cry of the soul. The proof of this idea follows from the phrase that broadcasts the heroine's protesting mood: il y avait d'autres hommes qu'Alan sur la terre. The lexemes maladroit and gâcher increase the concentration of negative evaluation of the situation.

In the following context, we observe the effect of the contextual influence on the transformation of the evaluative perspective of the utterance:

(2) "Il se moquait bien de son estime. D'ailleurs elle s'estimait trop peu elle-même pour que cela devienne contagieux: elle se contentait d'un rôle de garde-fou. A vingt-sept ans. Il y avait encore trois ans, elle était à Paris, elle vivait seule ou avec qui lui plaisait, elle respirait. A présent, elle transpirait dans ce décor de carton-pâte près d'un jeune homme névrosé qui ne savait pas lui-même ce qu'il attendait d'elle." (Sagan, 1961, p. 16).

Josée reflects on her own self-esteem, which has resisted change under the influence of intercourse with her neurotically sick husband. Her husband's unconcern for her esteem (il se moquait bien de son estime) had not influenced her (elle s'estimait trop peu elle-même pour que cela devienne contagieux) so she merely became content with the role of being his safety net (elle se contentait d'un rôle de garde-fou). The comparison with her former life in Paris, where she breathed freely (elle respirait) is stifling for her (elle transpirait dans ce décor de carton-pâte près d'un jeune homme névrosé). Absolute freedom (à Paris, elle vivait seule ou avec qui lui plaisait) is now limited to an enclosed space next to the neurotic husband. The usage of expressive vocabulary (s'en moquer, transpirer, garde-fou), metaphors (contagieux, décor de carton-pâte), ironic phrase (un jeune homme névrosé qui ne savait pas lui-même ce qu'il attendait d'elle), antitheses (se moquait - son estime; respirait - transpirait) creates a negative context which expresses the main character's despair.

In the utterances below, we can see the influence of the language employed on the context evaluation.

The main character, being under the constant obsessive control and oppression of her husband (3) "Oì qu'elle fût, le regard d'Alan la suivait." (Sagan, 1961, p. 113), realises that they gradually become enemies: (4) "Hostiles ... Voilà ce que nous sommes devenus; hostiles l'un à l'autre." (Sagan, 1961, p. 68). An acute sense of mutual hostility is transmitted through the reiteration of the lexeme with negative connotation hostiles in the plural and emphasises the mutual character of hostility; the punctuation mark of ellipsis (three dots of suspension) is an indicator of Josée's sad thoughts that she doesn't want to utter out loud.

Alan does not do anything, he does not work and their life is like a constant tourist trip. The adverb bien sûr stresses Josée's irritation and anger about Alan's idleness, about his not wanting to change the situation for the better: 
(5) "Alan bien sûr ne travaillait pas. Ils menaient une vie de touristes et cela ne contribuait pas peu à donner à Josée cette impression de provisoire, d'irréel." (Sagan, 1961, p. 114).

The feeling that their life is something temporary and unreal does not leave Josée. The epithets provisoire and irréel create the feeling of ephemerality and unreliability.

Josée understands that their relationship with Alan is more similar to the mother's custody for her baby:

(6) "Josée amenait Alan, comme une chatte, trimballe son petit, du bout des dents, par la peau du cou, prête à déguerpir avec lui au moindre danger." (Sagan, 1961, p. 111).

The comparative phrase comme une chatte trimballe son petit indicates almost an "animal" tie between them. Josée looks like a mother cat, dragging her cub with her, ready to escape at any moment in case of danger. The verb trimbaler has a familiar meaning and conveys "to carry someone or something carefully, usually at the cost of certain difficulties". The verb déguerpir completes a picture that conveys the "animal" reflex of the main character, capable of escaping with her young in the case of a panic situation.

In the following fragments, we notice that the assessment of the situation unexpectedly changes and the existence of Josée's different inner emotional life is revealed due to the mutual influence of the evaluative utterance and context:

(7) “Alan retira son bras et une seconde elle se sentit parfaitement perdue." (Sagan, 1961, p. 101).

It turns out that Josée is not at all self-sufficient and her determination disappears as soon as Alan takes his hand from her. She freezes for a moment and feels completely lost. The expression retirer le bras has a deep meaning: to stop showing a certain feeling towards someone (cesser d'accorder tel sentiment à qn), to lead to the loss of the right to use something (faire perdre l'usage d'un droit). It is the fear of losing something habitual that belonged to her that completely leads to a state of total helplessness.

There is another illustration of interrelation of context and the evaluative utterance:

(8) "Il se tournait vers elle. Depuis longtemps, elle ne l'avait pas vu habillé ainsi et cet homme en bleu marine, ce visage enfantin aux yeux durs lui étaient subitement étrangers. 'Alan', gémit une voix en ellemême, mais elle ne bougea pas" (Sagan, 1961, p. 67).

Josée, seeing her husband in a different situation, suddenly realises that this man in a dark blue suit with a childish expression on his face and a hard look is not familiar to her at all. She silently moaned "Alan". The verb gémir is an indicator of her inner contradictory state: on the one hand, she wants to avoid his hard look, on the other hand, this moan speaks about her deep sympathy and affection to him. Her love for him is shown by the usage of epithets ce visage enfantin (childish expression), aux yeux durs (hard look).

This idea can be verified by the following contexts:

(9) "Il y avait quelque chose d'irrésistible dans le regard qu'il posait sur elle, une telle expression de tendresse, d'acceptation, - qu'elle avait tout oublié." (Sagan, 1961, p. 118).

The phrase with evaluative words quelque chose d'irrésistible dans le regard shows Josée's weakness when she succumbed to Alan's charm. She could not resist the power of the gentleness (une telle expression de tendresse) and at the same time submissive look (d'acceptation) of her enemy and lover.

(10) "Ils restèrent longtemps ainsi l'un contre l'autre, comme deux lutteurs exténués" (Sagan, 1961, p. 189).

So they stood one against the other for a long time like two exhausted fighters. The phrase deux lutteurs exténués which is a metaphorical simile symbolises the end of a struggle and affection of Josée and Alan.

Thus, a pragmatic analysis of positive and negative evaluative utterances that permeate the novel made it possible to see and feel the depth of the contradictory love story of a young couple. It must be noted that evaluation served to create important and significant meanings for the whole text at its macro-level. This fact confirms the close interrelation between context and the polarity of utterance evaluation.

\section{Conclusions}

To sum up, having focused the research on the area of the evaluation actualisation in different types of context, we have traced the interrelation of context and evaluative utterance viewed from the standpoints of pragmatics, evaluation theory, theory of text, and theory of linguistic and stylistic context. The examination of context is realised in its organic connection with the object of the speaker's thought, or theme, which makes it possible to disclose the structure of context and to analyse profoundly the communicative status of contextual operations.

The study shows that the semantic units, being neutral at the language level, become evaluative in context. Such contexts can be termed as evaluative ones since only within their boundaries does the word acquire an evaluative meaning that is not inherent in its normative or emotionally-neutral usage. 
The notion of "evaluation" has become a central part of the conceptual apparatus of modern linguistics, which clearly displays the fact that it is impossible to study a language without resorting to its key purpose, its "creator", carrier, user, specific linguistic personality, or person.

It is clear that this evaluation is created, realised and thus can be interpreted only within the context. The important role in this process belongs to various expressive means and stylistic devices.

The present paper aims to provide proof that the evaluation contexts contribute to the creation and disclosure of the main semantic line of the whole text.

In conclusion, this study points out the necessity of the further research of evaluation in different types of context taking into account national stereotypes, complex language situations and literary genres.

\section{References:}

Akman, V. (2000). Rethinking Context as a Social Construct. Journal of Pragmatics. An Interdisciplinary Journal of Language Studies, 32 (6), 743-759. https://doi.org/10.1016/S0378-2166(99)00067-3

Arutyunova, N. (2012). Logicheskij analiz yazyka. Adresatsiya diskursa [Logical analysis of the language. Discourse addressing]. Moscow, Russia: Indrik.

Bally, Ch. (2001). Frantsuzskaya stilistika [French Stylistics]. Moscow, Russia: Editorial URSS.

Byessonova, O. (2012). Reconstruction of Value Concepts in the Language Model of the World. In M.Ferencik \& K. BednarovaGibova (Eds.), Language, Literature and Culture in a Changing Transatlantic World II. Part I: Linguistics, Translation and Cultural Studies (pp. 7-14). Prešov, Slovakia: Filozofická fakulta Prešovskej university v Prešove.

Bloomfield, L. (2010). Yazyk [Language]. Moscow, Russia: Editorial URSS.

Catford, J.C. (1974). A Linguistic Theory of Translation. Oxford: Oxford University Press.

Dijk, T. (2009). Society and Discourse. How Social Contexts Influence Text and Talk. New York: Cambridge University Press.

Dijk, T. (1977). Text and Context. London: Longman.

Fedoriv, Ya. (2016). Speaking to the global audience: A case study into the message transformation. Lege artis. Language yesterday, today, tomorrow, 1 (2), 1-36. http://dx.doi.org/ 10.1515/lart-2016-0009

Fetzer, A. (2004). Recontextualizing Context: Grammaticality Meets Appropriateness. Amsterdam / Philadelphia: John Benjamins Publishing Company.

Grice, H. (1975). Logic and conversation. In P. Cole \& J. Morgan (Eds.), Speech Acts (pp. 41-58). New York, USA: Academic Press.

Kachru, Y. (2008). Cultures, Contexts, and World Englishes. New York and London: Routledge.

Kecskes, I. (2013). Intercultural Pragmatics. Oxford: Oxford University Press.

Kolegaeva, I. (2017). Esho raz o roli signl'nyh system v poznanii i oznschivanii mira, ili pochemu tekut slyunki pri slove lemon [Once again about the role of the first and the second signal systems in cognizing and naming the world, or why do we salivate on hearing the word lemon]. Writings in Romance-Germanic Philology, 2 (39), 39-47. http://dx.doi.org/10.18524/2307-4604.2017.2(39).118611

Koseriu, E. (2010). Sinhroniya, diahroniya i istriya. Problema yazykovg izmeneniya [Synchrony, diachrony and history. The problem of language change]. Moscow, Russia: Editorial URSS.

Myroniuk, T. (2017). Evaluative Responses in Modern English Fiction. Advanced Education, 8, 103-108. https://doi.org/10.20535/ 2410-8286.108021

Partington, A. (2017). Evaluative clash, evaluative cohesion and how we actually read evaluation in texts. Journal of Pragmatics, 117, 190-203. https://doi.org/10.1016/j.pragma.2017.06.008

Prihodko, A. (2016). Katehoriia otsinky $v$ konteksti zminy linhvistychnykh paradyhm [The category of evaluation in the context of the change of linguistic paradigms]. Zaporizhzhia, Ukraine: Kruhozir.

Prihodko, G. (2018). Specific Nature of Evaluative Speech Acts. Advanced Education, 9, 201-205. https://doi.org/10.20535/24108286.128232

Sagan, F. (1961). Les merveilleux nuages. Paris: René Juliard.

Samokhina, V. \& Pasynok, V. (2017). Anthroponymic world in the text of the Anglophone joke. Lege artis. Language yesterday, today, tomorrow, II (2), 284-355. https://doi.org/10.1515/lart-2017-0018

Saveliuk, N. (2015). Kontekst yak systemnij chynnyk rozuminnya duskursu: filisofs'ki, lingvistychni ta psyhologichni aspekty [Context as a systematic factor of comprehending discourse: philosophical, linguistic and psychological aspects]. Kherson State University Herald, 1 (1), 61-65. Retrieved October 2018 from http://nbuv.gov.ua/UJRN/nvkhp_2015_1\%281\%29_14

Stanley, J. (2007). Language in Context: Selected Essays. Oxford, UK: Oxford University Press.

Vinogradov, V. (2001). Russkij yazyk: grammaticheskoje uchenije o slove [Russian language: grammatical theory of the word]. Moscow, Russia: The Russian Language.

Vol'f, E. (2009). Funktsional'naya semantika otsenki [Functional semantics of evaluation] (3d ed.). Moscow, Russia: Editorial URSS. 